\title{
OPEN Macroalgae in biomonitoring of metal pollution in the Bay of Bengal coastal waters of Cox's Bazar and surrounding areas
}

\author{
Md.Refat Jahan Rakib ${ }^{1 凶}$, Y. N. Jolly ${ }^{2}$, Diana Carolina Dioses-Salinas ${ }^{3}$, \\ Carlos Ivan Pizarro-Ortega ${ }^{3}$, Gabriel Enrique De-la-Torre ${ }^{3}$, Mayeen Uddin Khandaker ${ }^{4}$, \\ Abdullah Alsubaie ${ }^{5}$, Abdulraheem S. A. Almalki ${ }^{6}$ \& D. A. Bradley ${ }^{4,7}$
}

\begin{abstract}
Although coastal water marine algae have been popularly used by others as indicators of heavy metal pollution, data within the Bay of Bengal for the estuarine Cox's Bazar region and Saint Martin's Island has remained scarce. Using marine algae, the study herein forms an effort in biomonitoring of metal contamination in the aforementioned Bangladesh areas. A total of 10 seaweed species were collected, including edible varieties, analyzed for metal levels through the use of the technique of EDXRF. From greatest to least, measured mean metal concentrations in descending order have been found to be $\mathrm{K}>\mathrm{Fe}>\mathrm{Zr}>\mathrm{Br}>\mathrm{Sr}>\mathrm{Zn}>\mathrm{Mn}>\mathrm{Rb}>\mathrm{Cu}>\mathrm{As}>\mathrm{Pb}>\mathrm{Cr}>\mathrm{Co}$. Potential toxic heavy metals such as $\mathrm{Pb}, \mathrm{As}$, and $\mathrm{Cr}$ appear at lower concentration values compared to that found for essential mineral elements. However, the presence of $\mathrm{Pb}$ in Sargassum oligocystum species has been observed to exceed the maximum international guidance level. Given that some of the algae species are cultivated for human consumption, the non-carcinogenic and carcinogenic indices were calculated, shown to be slightly lower than the maxima recommended by the international organizations. Overall, the present results are consistent with literature data suggesting that heavy metal macroalgae biomonitoring may be species-specific. To the best of our knowledge, this study represents the first comprehensive macroalgae biomonitoring study of metal contamination from the coastal waters of Cox's Bazar and beyond.
\end{abstract}

Marine pollution began to be recognized and taken on importance since 1950 due to its consequences on human health through the intake of contaminated seafood/foodstuffs ${ }^{1}$. In fact, oceanic habitats are subject to a wide variety of pollutants, among them, heavy metals and trace elements took a significant position ${ }^{2}$. In recent decades, the marine environment shows increasing concentrations of these pollutants following large-scale urbanization, industrialization, and greater agricultural activities ${ }^{3,4}$. Heavy metals and metalloids from anthropogenic activities, including mining, milling, petrochemicals processing, electronics industry, and municipal waste, directly discharged into the marine environment or transported into the greater aquatic system via estuaries are of particular concern ${ }^{5}$. Particularly, heavy metals are transported from industrial wastewater, coastal aquifers, and ultimately seawater ${ }^{6}$. While adsorbents applied in wastewater treatment have been considered a suitable technological means for heavy metal removal, challenges nevertheless continue to remain ${ }^{7}$. Carbon-based materials (e.g. activated carbon and carbon nanotubes) synthesized from sustainable lignocellulosic residues have shown to be a particular area of promise within such efforts ${ }^{8,9}$. Likewise, anaerobic digestate from food waste in combination with sodium silicate binder has been used to produce biochar, with $\mathrm{Pb}$ removal capacity six times

\footnotetext{
${ }^{1}$ Department of Fisheries and Marine Science, Faculty of Science, Noakhali Science and Technology University, Noakhali, Bangladesh. ${ }^{2}$ Atmospheric and Environmental Chemistry Laboratory, Atomic Energy Centre, Dhaka 1000, Bangladesh. ${ }^{3}$ Universidad San Ignacio de Loyola, Av. La Fontana 501, Lima 12, Lima, Peru. ${ }^{4}$ Centre for Applied Physics and Radiation Technologies, School of Engineering and Technology, Sunway University, 47500 Bandar Sunway, Selangor, Malaysia. ${ }^{5}$ Department of Physics, College of Khurma, Taif University, P.O. Box 11099, Taif 21944, Saudi Arabia. ${ }^{6}$ Department of Chemistry, Faculty of Science, Taif University, Taif 21974,

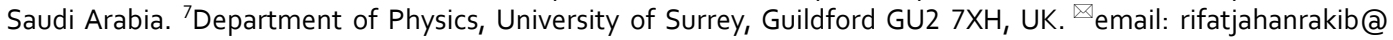
gmail.com
} 
greater than commercial activated carbon being found ${ }^{10}$. Overall, bioadsorbents are found to be effective and safe, representing low-cost alternatives for water treatment.

Consideration of solutions requires an ability to monitor their effectiveness. Accordingly, with the considerable ability of macroalgae to efficiently bioaccumulate heavy metals, macroalgae are considered valuable bioindicators of heavy metals contamination ${ }^{2,11}$.

Macroalgae are aquatic organisms that are present in almost all marine ecosystems ${ }^{12}$. In particular, macroalgae have high reproduction rates, leading to their high abundance and distribution in coastal environments ${ }^{13}$. They can be classified into three large groups: brown algae (Phaeophyceae), red algae (Rhodophyta), and green algae (Chlorophyceae). As examples of potentialities herein, Phaeophyceae, especially the order Fucales, can thrive in waters with high levels of heavy metals ${ }^{14}$. Likewise, green algae, especially the Ulvales order, are great bioindicators due to their high affinity with manganese $(\mathrm{Mn})$, iron $(\mathrm{Fe})$, copper $(\mathrm{Cu})$, zinc $(\mathrm{Zn})$, and lead $(\mathrm{Pb})^{15}$.

In other respects, including high lipid productivity, carbon dioxide capture, and low land requirement, these favor discussion of the suitability of algal biomass in biofuel production ${ }^{16,17}$. Of the several challenges that remain to be addressed, these include algae post-processing and cultivation processes ${ }^{18}$. Several algae species are able to produce bio-oil, as for example via catalytic pyrolysis involving gasification, also liquefaction processes ${ }^{19}$, the former being preferred due to their simplicity, high yields, and straightforward operations ${ }^{20}$.

It is also to be appreciated that many macroalgae are destined for human consumption as a result of their high nutritional value. For instance, Porphyra sp. (commercially known as Nori) is frequently consumed worldwide including in the Japanese delicacy "sushi". Also, among the brown algae, Laminaria spp. (Kombu), Undaria pinnatifida (Wakame) and Hizikia fusiforme (Hiziki) find considerable use in modern European and Asian cuisine ${ }^{21}$. Despite the presence of micronutrients in foodstuffs that are essential for human health, the trace elements have the potential to become highly toxic if certain levels are exceeded ${ }^{22,23}$. A review of the literature reveals that a considerable number of studies throughout the world have shown a greater concentration of heavy metals in seaweed. Pan et al. observed the high bioaccumulation capability of $\mathrm{Cu}, \mathrm{Cr}, \mathrm{Ni}, \mathrm{Zn}, \mathrm{Pb}, \mathrm{Cd}$, and As by seaweed collected from the Dongtou Islands of the East China Sea ${ }^{24}$. Dadolahi-Sohrab et al. reported elevated concentrations of $\mathrm{Pb}, \mathrm{Cd}, \mathrm{Cu}, \mathrm{Ni}, \mathrm{Zn}$, and Fe metals in 11 dominant seaweed species from the Strait of Hormuz ${ }^{25}$. A relatively high concentration of $\mathrm{Fe}$ and $\mathrm{Pb}$ in green and brown seaweeds collected from the Antikyra Gulf (Viotia, Greece) has been reported by Malea et al. ${ }^{26}$. Besada et al. showed that most edible algae contain elevated levels of cadmium with respect to the concentration limits suggested by European legislation ${ }^{27}$. Specifically, Hizikia fusiforme showed the highest concentrations of arsenic (As), which could pose a potential threat to human health. Arulkumar et al. determined very high concentrations of $\mathrm{Zn}$ and $\mathrm{Cu}$ in Ulva Lactuca samples from within India ${ }^{28}$. All of the aforementioned studies indicate that macroalgae have a great capability for bioaccumulating, storing, and persisting in retaining heavy metals and other trace elements, accordingly representing a potential threat to both local fauna and human health ${ }^{29}$.

Bangladesh is a low-lying, riverine South Asia country, with a coastline of $580 \mathrm{~km}$, located on the northern littoral of the Bay of Bengal. The coastal area, with both sandy and muddy beaches, estuaries, and mangrove swamps, provides a favourable habitat for various kinds of seaweed. As a result, in the coastal waters of Cox's Bazar and the Sundarbans regions more than 133 species of seaweed grow naturally with 14 of these having commercial value ${ }^{30}$. While it has been reported that some 5,000 metric tons of seaweed biomass are annually available in the coastal waters of Bangladesh ${ }^{31}$, nevertheless there is a lack of detailed information on the seaweeds production, distribution, availability of the commercially important species, and approaches for utilization in Bangladesh ${ }^{32}$. Of note is that the commercial value of seaweed is relatively unknown to the majority of Bangladeshi nationals, the numbers of individuals involved in seaweed cultivation in the south-eastern and south-western coasts of Bangladesh being limited. In particular, a small group in the Cox's Bazar region are noted to be occupied in the collection of seaweed in support of their livelihood, with additional involvement in the export of the medium to Myanmar, China, and Singapore ${ }^{33}$. Tribal populations within the country are also known to be using seaweed as a regular item within their dietary habit. Moreover, seaweed harvested in the country is also being used in the production of a wide range of items, including food, medicine, cosmetics, fertilizers, biofuels, and products to prevent environmental pollution ${ }^{33}$. However, to be the best knowledge of the authors, no earlier published studies are available concerning the quality or metal levels in the macroalgae found in the Cox's Bazar region.

Acknowledging the problems of seaweed contaminated by heavy metals and trace elements, effective monitoring of these contaminants is necessary, especially in respect of those regions within which high consumption of seaweed is known to be taking place.

While previous studies have shown bioaccumulation rates to differ among macroalgae species, characterization of this within the country is still lacking. Accordingly, the objectives of the present study have been to quantify the concentration of trace elements and heavy metals in different macroalgae species collected from the coastal waters of Cox's Bazar region and Saint Martin's Island, also to determine if the macroalgae are more likely to bioaccumulate trace elements based on their species or family (Rhodophyta, Chlorophyta, and Phaeophyceae). The results presented in this study offer such insights, providing groundwork in the biomonitoring of specific algae for heavy metals contamination. Moreover, human health hazard risks (carcinogenic and noncarcinogenic) have also been calculated for the heavy metals that have been found herein to be manifesting at potentially toxic levels, account being taking of consumption behavior.

\section{Materials and methods}

Study site and sampling. The coastal region of Cox's Bazar and Saint Martin's Island, along the northern littoral of the Bay of Bengal (Fig. 1) have been selected for sample collection. The coastline of Cox's Bazar is the longest sandy beach in the world $(125 \mathrm{~km})$, including natural landscapes, tertiary hills, sand dunes, etc., all 

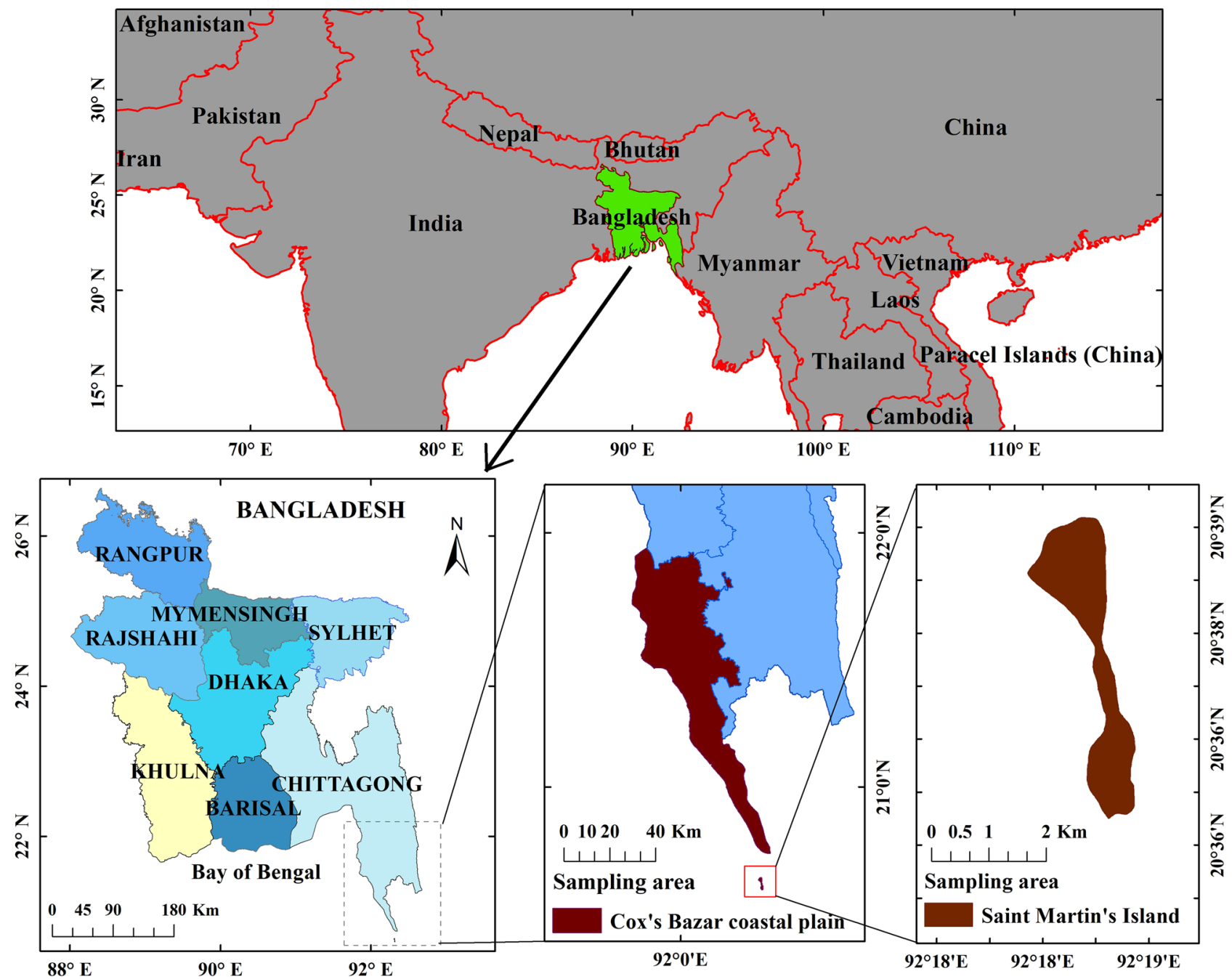

Figure 1. Map of the sampling locations in Cox's Bazar and Saint Martin's Island. The map was constructed using ArcGIS 10.7.

\begin{tabular}{|l|l|l|}
\hline Sample code & Seaweed species & Family \\
\hline R1 & Hypnea musciformis & Rhodophyta \\
\hline R2 & Hypnea pannosa & Rhodophyta \\
\hline R3 & Jania Rubens & Rhodophyta \\
\hline R4 & Gelidium pusillum & Rhodophyta \\
\hline B5 & Padina tetrastromatica & Phaeophyta \\
\hline B6 & Sargassum oligocystum & Phaeophyta \\
\hline B7 & Padina boryana & Phaeophyta \\
\hline G8 & Caulerpa racemosa & Chlorophyta \\
\hline G9 & Enteromorpha intestinalis & Chlorophyta \\
\hline G10 & Ulva compressa & Chlorophyta \\
\hline
\end{tabular}

Table 1. Identity and labeling of the 10 seaweed species collected. "R", "B", and "G" indicate red, brown, and green seaweed respectively.

making the location highly attractive, typically with millions of tourists visiting the area annually, with multiple businesses associated with the tourism industry present along the coastline area ${ }^{34}$.

Over the period January 2018 to April 2019, ten naturally growing seaweed species samples were collected (Table 1), each in triplicate, obtained from different sites in the Cox's Bazar and Saint Martin region of Chittagong (Fig. 1). Species and taxonomy identification followed standard morphological features, size, shape, color, etc. The samples were thoroughly rinsed to remove adhered sediments and other substances. To mitigate against the 


\begin{tabular}{|l|c|r|l|l|l|l|}
\hline Element & Results obtained $\left(\mathbf{m g ~ k g}^{-1}\right)$ & \pm SD & Certified values $\left(\mathbf{m g ~ k g}^{-1}\right)$ & Relative error (\%) & CV (\%) & Recovery (\%) \\
\hline $\mathrm{K}$ & $27,354.7$ & 840.1 & 29,030 & 5.77 & 3.07 & 94.2 \\
\hline $\mathrm{Mn}$ & 78.62 & 2.27 & 75.90 & -3.59 & 2.89 & 103.6 \\
\hline${ }^{a} \mathrm{Fe}$ & 325.67 & 22.30 & 300 & -8.56 & 6.76 & 108.6 \\
\hline $\mathrm{Cu}$ & 13.24 & 0.44 & 12.20 & -8.56 & 3.39 & 108.6 \\
\hline $\mathrm{Zn}$ & 84.11 & 1.85 & 82.00 & -2.57 & 2.20 & 102.6 \\
\hline${ }^{a} \mathrm{As}$ & 9.13 & 0.21 & 10.00 & 8.67 & 2.28 & 91.3 \\
\hline $\mathrm{Sr}$ & 55.21 & 0.41 & 55.60 & 0.71 & 0.74 & 99.3 \\
\hline${ }^{a} \mathrm{~Pb}$ & 40.38 & 1.14 & 45.00 & 10.26 & 2.82 & 89.7 \\
\hline
\end{tabular}

Table 2. Comparison of measurement and certified values ( $\mathrm{mg} \mathrm{kg}^{-1}$, dry weight of CRM Spinach/NIST 1570a. ${ }^{\mathrm{a} C}$ Certified reference material Orchard leaf/NIST 1571.

effects of natural decay and consequent influence on metals analysis, the samples in labeled plastic bags were quickly transported to the lab for subsequent processing.

Sample preparation. The procedure described by Jolly et al. was adopted in preparing the samples for analysis, the latter via the technique of Energy Dispersive X-ray Fluorescence (EDXRF), in the Atmospheric and Environmental Chemistry Laboratory of the Atomic Energy Centre, Dhaka ${ }^{35}$. In specific terms, the preparation procedures consisted of cutting seaweed samples into small pieces, washed with tap water, and subsequently rinsed with deionized water, to then be left to dry at room temperature, followed by placement in an oven at $60{ }^{\circ} \mathrm{C}$ until a constant dry weight was obtained. The dried seaweeds were then ground to obtain a fine homogenous powder using an agate mortar and pestle, with $0.1 \mathrm{~g}$ masses being pelletized using a hydraulic press pellet maker model (Specac Ltd., UK) by applying a pressure of approximately 3 tons. The dimension of the prepared pellets was $7 \mathrm{~mm}$ in diameter and $1 \mathrm{~mm}$ thick. This procedure was carried out for each triplicate of the 10 seaweed species. The pellets were then stored in clean glass Petri dishes, then held in a vacuum desiccator for subsequent measurement of the concentrations of the various metals of concern.

Sample analysis and method validation of the level of concern metals. The elemental concentration was analyzed by energy-dispersive X-ray fluorescence (EDXRF) spectroscopy, as described in our previous study ${ }^{36}$. In brief, a ${ }^{109} \mathrm{Cd}$ point source with an X-ray beam (at $22.4 \mathrm{keV}$ ) was applied to excite the prepared samples and produce characteristic X-ray detected by the $\mathrm{Si}(\mathrm{Li})$ detector (Canberra ${ }^{\mathrm{Tu}}$ ) which has a resolution of $175 \mathrm{eV}$ at $5.9 \mathrm{keV}$, amplified by the spectroscopy amplifier and processed by the multichannel analyzer MCA ( $6 \mathrm{~K}+$ channel). All the peak areas were integrated by AXIL and PRO/QXAS software provided by the International Atomic Energy Agency (IAEA), Vienna, Austria.

With EDXRF a direct comparison method for elemental concentration measurement, calibration curves must be constructed based on similar matrices. Improving the sensitivity of readings and nullifying the matrix effects, the calibration curves were constructed via the use of the commercially available standard reference material (SRM) Orchard leaf/NIST 1571. The average peak areas of the EDXRF irradiated SRM pellets (at least three pellets) prepared using a similar configuration to that of the algae samples were then plotted in terms of the presence of the elements as a function of atomic number ${ }^{36}$. Validation of the calibration curve constructed for elements present in the standards was performed via analysis of another standard reference material, Spinach/ NIST 1570 a, again prepared in the same way as the algae sample ${ }^{35}$. All the obtained values were similar to certified values, the percentage relative error in evaluated elements being $<10 \%$, assuring validation of the method. Comparison between the experimental and certified values is provided in Table 2.

Samples were positioned in the EDXRF spectrometer according to the defined geometry and then excited using a ${ }^{109} \mathrm{Cd}$ point source, providing $22.4 \mathrm{keV}$ X-rays. To obtain good counting statistics, each sample was irradiated for a sufficient duration, ranging from 2000 to $5000 \mathrm{~s}$. The collected spectra were analyzed using the aforementioned software, obtained from the IAEA. In this study, the standard addition method was used to obtain the metal concentration. The method involves the addition of known quantities of various analytes to the specimen. This method requires a linear calibration throughout the range of addition of various analytes. To determine each of the elements in the obtained spectrum, use was made of the calibration curves, also acknowledging an absence of inter-elemental effects; determination of metal concentrations in the analyzed algae sample was made via Eq. (1) as follows:

$$
I_{i}=C_{i} \cdot S_{i} \cdot A
$$

with $I_{i}$ the characteristic X-ray net intensity (in cps), $C_{i}$ the metal concentration (in $\mu \mathrm{g} . \mathrm{g}^{-1}$ ), $S_{i}$ the sensitivity of each analyzed element $i\left(\mathrm{cps} \cdot \mathrm{g}^{-1} \cdot \mathrm{cm}^{2}\right)$, and A the absorption factor, equal to 1 for the samples, prepared in a thin-film geometry.

Determination of the limit of detection. The Minimum Detection Limit (MDL) depends on the counting statistics of the measurement and is a statistical process ${ }^{37}$. The MDL is obtained from the ratio of the amount of an element (in ppm) yielding an X-ray intensity equal to $3 \sigma$ of the background under the peak in an interval 


\begin{tabular}{|l|l|}
\hline Element & MDL $\left(\mathrm{mg} \mathrm{kg}^{-1}\right)$ \\
\hline $\mathrm{K}$ & 8.09 \\
\hline $\mathrm{Cr}$ & 0.29 \\
\hline $\mathrm{Mn}$ & 0.27 \\
\hline $\mathrm{Fe}$ & 0.54 \\
\hline $\mathrm{Co}$ & 0.17 \\
\hline $\mathrm{Cu}$ & 0.13 \\
\hline $\mathrm{Zn}$ & 0.35 \\
\hline $\mathrm{As}$ & 0.02 \\
\hline $\mathrm{Sr}$ & 0.19 \\
\hline $\mathrm{Pb}$ & 0.12 \\
\hline
\end{tabular}

Table 3. MDL values $\left(\mathrm{mg} \mathrm{kg}^{-1}\right)$ of most analyzed elements.

equal to the full width at half maximum (FWHM) of the peak and the concentration of the corresponding elements determined by using the calibration procedure ${ }^{38}$, and calculated using relation (2):

$$
M D L(x)=\frac{3 \sigma \text { counts of element ' } \mathrm{x} \text { ' in the sample }}{\frac{\text { Counts }}{\mathrm{ppm}} \text { of element ' } \mathrm{x} \text { ' in the standard }}
$$

where $\sigma=\sqrt{\frac{\text { Background }}{\text { Channel }} \times F W H M}$ of the relevant element.

The calculated MDL for the analyzed elements is displayed in Table 3.

Metal pollution index (MPI). The heavy metal burden of the 10 seaweed species was estimated on the basis of a metal pollution index (MPI), calculated using the following formula ${ }^{39}$ :

$$
M P I=\left(M_{1} \times M_{2} \times \ldots \times M_{n}\right)^{1 / n}
$$

with $M_{n}$ the mean concentration of heavy metal $\mathrm{n}\left(\mathrm{mg} \mathrm{kg}^{-1}\right.$ dry weight). The metals included in the analyses were $\mathrm{As}, \mathrm{Pb}$, and $\mathrm{Cr}$.

Health risk assessment. Non-carcinogenic risk. A health risk assessment for an average adult was conducted following Ref. ${ }^{28}$, based on the method of the US Enviromental Protection Agency (EPA $)^{40}$. The targeted hazard quotient (THQ) and hazard index (HI) was calculated based on the exposed dose (ED), the latter calculated using the following Eq. (4):

$$
E D=\frac{C_{i} \times D_{i} \times E_{d}}{B_{w} \times A_{t}}
$$

with $\mathrm{C}_{\mathrm{i}}$ the mean concentration of heavy metals in seaweed $\left(\mathrm{mg} \mathrm{kg}^{-1}\right), \mathrm{D}_{\mathrm{i}}$ the daily seaweed intake $(5.2 \mathrm{~g}$ person $^{-1}$ day $\left.^{-1}\right), E_{d}$ the average duration of exposure (70 years), $B_{w}$ the average body weight of the consumer $(70 \mathrm{~kg})$, and $\mathrm{A}_{\mathrm{t}}$ the lifetime of the consumer (70 years), the values being from recognized reference data.

The THQ, characterizing the non-carcinogenic risk to an exposed individual, is defined as the ratio of the exposed dose of a particular metal to the corresponding reference dose $\left(\mathrm{R}_{\mathrm{f}} \mathrm{D}\right)$ and can be determined by the following Eq. (5):

$$
T H Q=\frac{E D}{R_{f} D}
$$

where $\mathrm{R}_{\mathrm{f}} \mathrm{D}$ is the recommended oral reference dose for certain metals. Lastly, hazard index (HI) is calculated following Eq. (6):

$$
H I=\sum T H Q
$$

Following the US $\mathrm{EPA}^{40}$ guidelines, a $\mathrm{HI}<1$ is regarded to offer no potential health risk.

Carcinogenic risk. The carcinogenic risk (CR) was assessed following Kortei et al. based on the methodology by the US EPA ${ }^{41}$, using Eq. $(7)^{42}$ :

$$
C R=E D \times C S F
$$

where CSF is the cancer slope factor. The CSF values of carcinogenic metals are displayed in Table 4 . The total cancer risk $\left(\mathrm{CR}_{\mathrm{t}}\right)$ was determined as the sum of the $\mathrm{CR}$ from the studied heavy metals ${ }^{43}$, as displayed in Eq. (8):

$$
C R_{t}=\sum C R
$$




\begin{tabular}{|l|l|l|}
\hline Metal & CSF $\left(\mathrm{m} \mathrm{kg}^{-1} \mathbf{d a y}^{-1}\right)$ & References \\
\hline As & 1.5 & 43 \\
\hline $\mathrm{Pb}$ & $8.5 \times 10^{-3}$ & 42 \\
\hline $\mathrm{Cr}$ & 0.5 & 43 \\
\hline
\end{tabular}

Table 4. Cancer slope factor values for $\mathrm{As}, \mathrm{Pb}$, and $\mathrm{Cd}$.

\begin{tabular}{|l|c|c|}
\hline \multirow{2}{*}{ Element } & \multicolumn{2}{|c|}{ Concentration } \\
\cline { 2 - 3 } & Wet weight & Dry weight \\
\hline $\mathrm{K}$ & $41,234.0$ & 6185.1 \\
\hline $\mathrm{Cr}$ & 1.15 & 0.17 \\
\hline $\mathrm{Mn}$ & 32.9 & 4.9 \\
\hline $\mathrm{Fe}$ & 1971.5 & 295.7 \\
\hline $\mathrm{Co}$ & 0.26 & 0.04 \\
\hline $\mathrm{Cu}$ & 16.6 & 2.5 \\
\hline $\mathrm{Zn}$ & 34.5 & 5.2 \\
\hline $\mathrm{As}$ & 3.4 & 0.50 \\
\hline $\mathrm{Br}$ & 63.7 & 9.6 \\
\hline $\mathrm{Rb}$ & 28.0 & 4.2 \\
\hline $\mathrm{Sr}$ & 39.8 & 6.0 \\
\hline $\mathrm{Zr}$ & 78.5 & 11.8 \\
\hline $\mathrm{Pb}$ & 2.6 & 0.39 \\
\hline
\end{tabular}

Table 5. Mean concentrations of trace elements and heavy metals in the 10 species of algae collected from the coastal waters of the Cox's Bazar region.

Statistical analysis. Metal concentrations in seaweed were expressed in $\mathrm{mg} / \mathrm{kg} \pm$ standard error of the mean ( $\left.\mathrm{mg} \mathrm{kg}^{-1} \pm \mathrm{SEM}\right)$. To allow meaningful comparison, dry weight (d.w.) concentrations were converted to wet weight (w.w.) values using the simple formula ${ }^{37}$ :

$$
\operatorname{Concentration}(w . w .)=\frac{(100-\% \text { of water in seaweed })}{100} \times \operatorname{Concentration}(\text { d.w. })
$$

Given that seaweed generally contains $80-90 \%$ water ${ }^{44}$, a median value of $85 \%$ was used for the calculations.

An ordinary one-way analysis of the variance (ANOVA) was conducted to compare the concentrations of the 13 observed elements among the 10 seaweed species, followed by Tukey's multiple comparisons test. The same analyses were used to compare the concentration of the elements among types (Chlorophyta, Rhodophyta, and Phaeophyceae) by grouping seaweed species of the same color. Statistical significance was set to 0.05 . All the analyses and graphs were performed in GraphPad Prism (version 8.4.3 for Windows).

\section{Results and discussion}

A total of 13 elements were determined and validated by the EDXRF technique for the 10 macroalgae species. Overall, the mean concentration of trace elements and heavy metals in the 10 species decreased in the descending order $\mathrm{K}>\mathrm{Fe}>\mathrm{Zr}>\mathrm{Br}>\mathrm{Sr}>\mathrm{Zn}>\mathrm{Mn}>\mathrm{Rb}>\mathrm{Cu}>\mathrm{As}>\mathrm{Pb}>\mathrm{Cr}>\mathrm{Co}$ (Table 5). The mean elemental concentration and descriptive statistics per macroalgae species are displayed in Table S1. As expected, K provides the greatest concentration among the 10 species (mean of $4.2 \times 10^{4} \mathrm{mg} \mathrm{kg}^{-1}$ ), being significantly greater than the second most prevalent element ( $\mathrm{Fe}$, with a mean of $1.9 \times 10^{3} \mathrm{mg} \mathrm{kg}^{-1}$ ). Previous studies have shown the prevalence of $\mathrm{K}$ to be in the same order. For instance, in Ulva spp. (Ireland), Chondrus crispus (Denmark), and Fucus spiralis (Spain), the mean $\mathrm{K}$ respective concentrations were $1.2 \times 10^{4}, 3.3 \times 10^{4}$, and $4.0 \times 10^{4} \mathrm{mg} \mathrm{kg}^{-145-47}$. Seaweeds naturally contain high $\mathrm{K}$ content, at of the order of $2 \%$ of their dry weight ${ }^{48,49}$, depending on the species and environmental conditions. Co concentrations have been found to be the lowest in value, at a mean of $0.26 \mathrm{mg} \mathrm{kg}^{-1}$ (ranging from 0.18 to $0.33 \mathrm{mg} \mathrm{kg}^{-1}$ across the species); lower Co content has been reported in commercial seaweed of Asian origin (mean of $0.10 \mathrm{mg} \mathrm{kg}^{-1}$ ) and European origin (mean of $\left.0.03 \mathrm{mg} \mathrm{kg}^{-1}\right)^{50}$, constituting a naturally occurring micronutrient in seaweed ${ }^{51}$. Previous studies in aqueous solutions have demonstrated the leaching of elements such as $\mathrm{Ca}$ and $\mathrm{Mg}$ from grasses/algae, directly measured via inductively coupled plasma mass spectrometry $(\mathrm{ICP}-\mathrm{MS})^{52}$. In the present study, macroalgae samples were not analyzed in aqueous solutions, thus leaching and loss of metallic elements from the samples being unlikely to have occurred.

One-way ANOVA analysis shows a significant difference in the concentration of elements among macroalgae species $(p=<0.05)$, except for Co $(p=0.3669)$ (Fig. 2a). Regarding the determined hazardous heavy metals, $\mathrm{Pb}$, As, and $\mathrm{Cr}$; the highest mean concentrations of $\mathrm{Pb}$ were found in $\mathrm{B} 6\left(10.63 \mathrm{mg} \mathrm{kg}^{-1}\right)$, followed by R4 (4.50 mg kg-1), and B5 (4.24 mg kg-1) (Fig. 2b). For arsenic, two species, B5 (11.89 $\left.\mathrm{mg} \mathrm{kg}^{-1}\right)$ and B6 

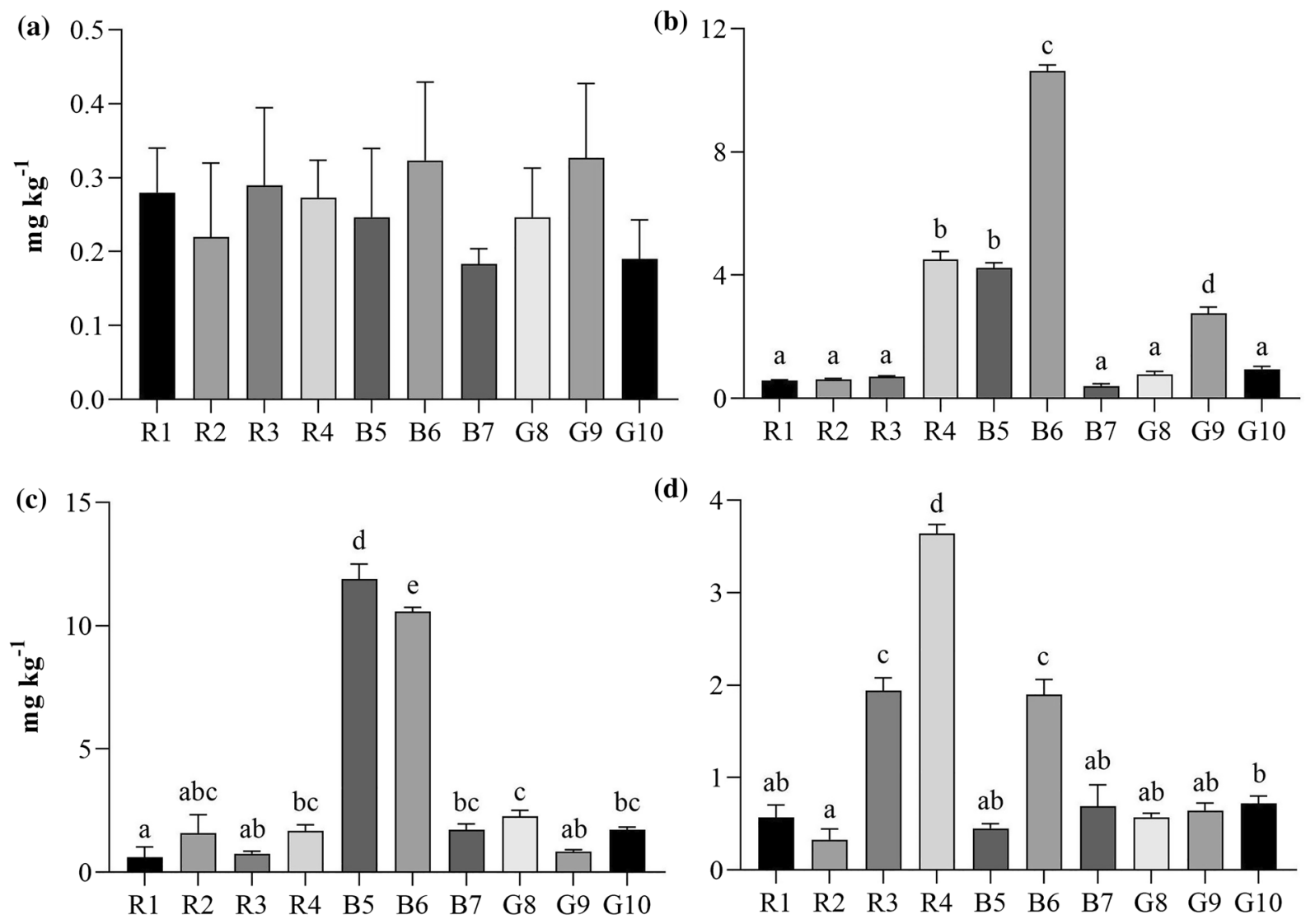

Figure 2. Mean concentration of (a) $\mathrm{Co},(\mathbf{b}) \mathrm{Pb},(\mathbf{c}) \mathrm{As}$, and (d) $\mathrm{Cr}$ in the 10 algae species evaluated. Error bars indicate standard deviation. Letters indicate significant differences.

(10.75 $\mathrm{mg} \mathrm{kg}^{-1}$ ) had significantly higher concentrations than the rest (Fig. 2c). Lastly, R4 (3.64 mg kg-1), R3 (1.94 mg kg $\mathrm{g}^{-1}$ ), and B6 (1.90 $\mathrm{mg} \mathrm{kg}^{-1}$ ) presented the highest levels of Cr (Fig. 2d). Interestingly, macroalgae species from the same genus (Hypnea; R1 and R2) showed similar bioaccumulation of heavy metals. B5 and B7 (both genius Padina), showed considerable differences. This suggests that despite similar mechanisms of uptake, total nutrient/metal uptake may be species-specific for some seaweed genera.

Despite being consumed as food or utilized as animal feed, there is no current legislation in Bangladesh that determines the maximum levels of heavy metals in seaweed. However, some international norms are available. $\mathrm{Pb}$ concentration in B6 surpassed the maximum levels in seaweeds $\left(5 \mathrm{mg} \mathrm{kg}^{-1}\right)$ recommended by the French High Council for Public Health ${ }^{53}$ and The Center for the Study and Development of Algae (CEVA) ${ }^{28}$. Moreover, the maximum levels of $\mathrm{Pb}$ in leafy vegetables (which may be consumed at similar levels to that of seaweed), according to the $\mathrm{FAO}^{54}$, is much lower (at $0.3 \mathrm{mg} \mathrm{kg}^{-1}$ ). To the best of our knowledge, maximum As and Cr levels in seaweed have not been addressed in international regulations. It should be noted that Sargassum sp. along with four additional species in the present study (R2, R4, G8, and G9) have been cultured and consumed in fresh or dried form for decades in Bangladesh ${ }^{32}$, thus presenting a potential route for heavy metal exposure to the population. Nevertheless, seaweed cultivation in Cox's Bazar remains artisanal and undeveloped ${ }^{31}$.

The concentrations of the three potentially toxic heavy metals that have been considered herein, Cr, As, and $\mathrm{Pb}$, have been found comparable or lower than literature data elsewhere (Table 6). For instance, the mean concentration of $\mathrm{Pb}$ in 12 algal species in China was $1.89 \mathrm{mg} \mathrm{kg}^{-1}$ (ranging from 0.77 to $4.21 \mathrm{mg} \mathrm{kg}^{-1}$ ) ${ }^{24}$. In Lebanon, concentrations were even lower, with a mean of $1.04 \mathrm{mg} \mathrm{kg}^{-155}$. Cr and As were particularly high in Greece and China, with mean concentrations of 9.38 and $18.33 \mathrm{mg} \mathrm{kg}^{-1}$ respectively ${ }^{1,24,56}$. Conversely, much lower concentrations were reported from a market survey in Italy $\mathrm{y}^{50}$. The mean concentrations of $\mathrm{Cr}, \mathrm{As}$, and $\mathrm{Pb}$ were $0.14,1.42$, and $0.13 \mathrm{mg} \mathrm{kg}^{-1}$, respectively. This may be attributed to the high hygiene standards through the food supply chain and also during seaweed culture intended for human consumption. In markets from the Canary Islands (of Spain) reported $\mathrm{Pb}$ concentrations in seaweeds of Asian and European origin have ranged from 0.12 to $0.004 \mathrm{mg} \mathrm{kg}^{-1}$ and from < LOQ to $0.05 \mathrm{mg} \mathrm{kg}^{-1}$, respectively ${ }^{57}$. The importation of potentially contaminated edibles as a source of heavy metal exposure has been discussed by others, including in regard to the consumption of seaweed. Particular examples include toxic industrial discharges in India, with toxic heavy metal pollution in areas of plant cultivation being a particular consequence ${ }^{58}$. A recent study carried out along the Palk Bay coast of southeast India has observed highly elevated $\mathrm{Pb}$ concentrations in many seaweed species, surpassing $10 \mathrm{mg} \mathrm{kg}^{-1}$ in many cases. The variation in concentrations was found to depend on the sampling season. The main sources of contamination have been linked to ship washing activities, seafood processing, domestic sewage, and effluent 


\begin{tabular}{|c|c|c|c|c|c|c|}
\hline Country of study & Species & Tissue & $\mathrm{Cr}$ & As & $\mathbf{P b}$ & Ref \\
\hline \multirow{10}{*}{ Bangladesh } & Hypnea musciformis & \multirow{10}{*}{ Thalli } & $0.57 \pm 0.08$ & $0.60 \pm 0.25$ & $0.59 \pm 0.01$ & \multirow{10}{*}{ This study } \\
\hline & Hypnea pannosa & & $0.33 \pm 0.07$ & $1.60 \pm 0.43$ & $0.62 \pm 0.02$ & \\
\hline & Jania rubens & & $1.94 \pm 0.08$ & $0.76 \pm 0.06$ & $0.71 \pm 0.01$ & \\
\hline & Gelidium pusillum & & $3.64 \pm 0.06$ & $1.68 \pm 0.14$ & $4.50 \pm 0.15$ & \\
\hline & Padina tetrastromatica & & $0.45 \pm 0.03$ & $11.89 \pm 0.35$ & $4.24 \pm 0.10$ & \\
\hline & Sargassum oligocystum & & $1.90 \pm 0.09$ & $10.57 \pm 0.10$ & $10.63 \pm 0.11$ & \\
\hline & Padina boryana & & $0.69 \pm 0.13$ & $1.70 \pm 0.14$ & $0.40 \pm 0.04$ & \\
\hline & Caulerpa racemose & & $0.57 \pm 0.03$ & $2.27 \pm 0.14$ & $0.77 \pm 0.06$ & \\
\hline & Enteromorpha intestinalis & & $0.64 \pm 0.05$ & $0.84 \pm 0.05$ & $2.76 \pm 0.12$ & \\
\hline & Ulva compressa & & $0.72 \pm 0.04$ & $1.72 \pm 0.07$ & $0.95 \pm 0.05$ & \\
\hline \multirow{4}{*}{ Greece } & Gracilaria gracilis & \multirow{4}{*}{ Thalli } & $3.89 \pm 1.18$ & $4.46 \pm 1.07$ & $4.24 \pm 1.54$ & \multirow{4}{*}{56} \\
\hline & Codium fragile & & $10.46 \pm 4.84$ & $4.25 \pm 0.49$ & $3.89 \pm 2.02$ & \\
\hline & Ulva intestinalis & & $13.80 \pm 2.96$ & $1.50 \pm 0.47$ & $4.62 \pm 1.19$ & \\
\hline & Ulva ridiga & & $9.38 \pm 1.50$ & $1.45 \pm 0.25$ & $3.06 \pm 0.67$ & \\
\hline Lebanon & Ulva lactuca & N.S & $1.08 \pm 0.90$ & $4.78 \pm 3.60$ & $1.04 \pm 1.03$ & 55 \\
\hline \multirow{12}{*}{ China } & Sargassum fusiforme & \multirow{12}{*}{ N.S } & $0.85 \pm 0.11$ & $57.71 \pm 13.44$ & $1.50 \pm 0.62$ & \multirow{12}{*}{24} \\
\hline & Sargassum thunbergii & & $3.84 \pm 0.47$ & $49.08 \pm 2.46$ & $2.00 \pm 0.24$ & \\
\hline & Sargassum vachellianum & & $1.21 \pm 0.12$ & $23.77 \pm 3.88$ & $1.90 \pm 0.39$ & \\
\hline & Pachydictyon coriaceum & & 5.90 & 16.12 & 3.34 & \\
\hline & Polyopes polyideoides & & $0.92 \pm 0.25$ & $15.41 \pm 0.05$ & $1.32 \pm 0.11$ & \\
\hline & Gelidium divaricatum & & $6.83 \pm 1.11$ & $8.89 \pm 1.07$ & $4.21 \pm 0.64$ & \\
\hline & Gracilaria lemaneiformis & & 0.86 & 8.31 & 0.90 & \\
\hline & Ahnfeltiopsis flabelliformis & & $1.16 \pm 0.03$ & $4.81 \pm 0.74$ & $1.09 \pm 0.09$ & \\
\hline & Laurencia tropica & & $3.01 \pm 0.18$ & $9.72 \pm 2.70$ & $1.92 \pm 0.19$ & \\
\hline & Pterocladiella capillacea & & $1.89 \pm 0.23$ & $3.35 \pm 0.23$ & $1.58 \pm 0.04$ & \\
\hline & Chondracanthus intermedius & & $1.04 \pm 0.07$ & $15.41 \pm 0.25$ & $0.77 \pm 0.12$ & \\
\hline & Ulva pertusa & & 2.05 & 7.35 & 2.18 & \\
\hline \multirow{8}{*}{ Italy } & Himanthalia sp. & \multirow{8}{*}{ N.S } & $0.1 \pm 0.04$ & $0.39 \pm 0.51$ & $0.06 \pm 0.03$ & \multirow{8}{*}{50} \\
\hline & Saccharina sp. & & $0.08 \pm 0.03$ & $0.87 \pm 0.88$ & $0.17 \pm 0.39$ & \\
\hline & Undaria sp. & & $0.12 \pm 0.06$ & $1.37 \pm 1.64$ & $0.10 \pm 0.07$ & \\
\hline & Ascophyllum sp. & & 0.23 & 0.09 & 0.11 & \\
\hline & Laminaria sp. & & 0.13 & 7.14 & 0.11 & \\
\hline & Porphyra sp. & & $0.08 \pm 0.10$ & $1.27 \pm 1.37$ & $0.17 \pm 0.30$ & \\
\hline & Palmaria sp. & & $0.11 \pm 0.06$ & $0.09 \pm 0.05$ & $0.14 \pm 0.21$ & \\
\hline & Ulva sp. & & $0.30 \pm 0.18$ & $0.12 \pm 0.09$ & $0.16 \pm 0.12$ & \\
\hline \multirow{2}{*}{ China } & Porphyra sp. & \multirow{2}{*}{ N.S } & $1.64 \pm 0.08$ & $36.67 \pm 0.53$ & $0.96 \pm 0.03$ & \multirow{2}{*}{79} \\
\hline & Laminaria sp. & & $3.78 \pm 0.56$ & $43.85 \pm 1.42$ & $0.61 \pm 0.03$ & \\
\hline
\end{tabular}

Table 6. The concentration of potentially toxic heavy metals in various studies. N.S. Not Specified.

discharges. In the case of boat maintenance procedures, the application of antifouling paint has been noted, the particles of these containing metallic-based biocides that can detach from the marine coatings ${ }^{59}$.

The concentrations of most of the remaining trace elements $(\mathrm{Mn}, \mathrm{Cu}, \mathrm{Zn}, \mathrm{Br}, \mathrm{Rb}$, and $\mathrm{Sr}$ ) have been found to be in the range $\sim 5$ to $75 \mathrm{mg} \mathrm{kg}^{-1}$ (Fig. 3). Additionally, the mean Fe ranged from $1487 \mathrm{mg} \mathrm{kg}^{-1}$ in P. tetrastromatica to $3352 \mathrm{mg} \mathrm{kg}^{-1}$ in $H$. pannosa. Most of these elements are micronutrients involved in natural algae metabolism ${ }^{60}$. The concentration of micronutrients found in the present study is mostly of the same order of magnitude as that reported by Roleda et al. ${ }^{61}$. Seaweeds in particular are considered a great source of $\mathrm{Fe}^{62}$, which could increase the proportion of absorbed iron in functional meals ${ }^{63}$. Sr is known to be related to cell wall polysaccharides found in some macroalgae, such as alginates in most Phaeophyceae, and generally exhibit low concentrations ${ }^{64}$. Although $\mathrm{Rb}$ is not widely studied, it is suggested to be related to the geochemistry of the coastal environments ${ }^{65}$. Algae are noted to use the bromine and chlorine present in the environment to biosynthesize halogenated secondary metabolites ${ }^{66}$, many of the halogenated compounds being found to be brominated.

Concerning seaweed type, most of the studied metals show insignificant differences except for $\mathrm{Mn}, \mathrm{Fe}, \mathrm{As}, \mathrm{Br}$, $\mathrm{Zr}$, and $\mathrm{Pb}$ (Table 7). The results of the Kruskal-Wallis test and literature suggest that the seaweed type may not be as significant as the species in determining the bioaccumulation of metals in the seaweed. For instance, Rubio et al. analyzed 20 metals, finding no significant differences between Phaeophyta and Rhodophyta for the majority of the studied metals, the exceptions being $\mathrm{Cr}, \mathrm{Cu}, \mathrm{Fe}, \mathrm{Li}, \mathrm{Mn}, \mathrm{Mo}, \mathrm{Sr}, \mathrm{V}$, and $\mathrm{Zn}^{67}$. In contrast, Filippini et al. performed a similar analysis with 21 metals comparing Phaeophyta, Rhodophyta, and Chlorophyta, finding significant differences in the majority of studied metals, the exceptions being for $\mathrm{Pb}, \mathrm{Hg}, \mathrm{Mn}, \mathrm{Co}$, $\mathrm{Ti}$, and $\mathrm{Sb}^{50}$. Some comparative 


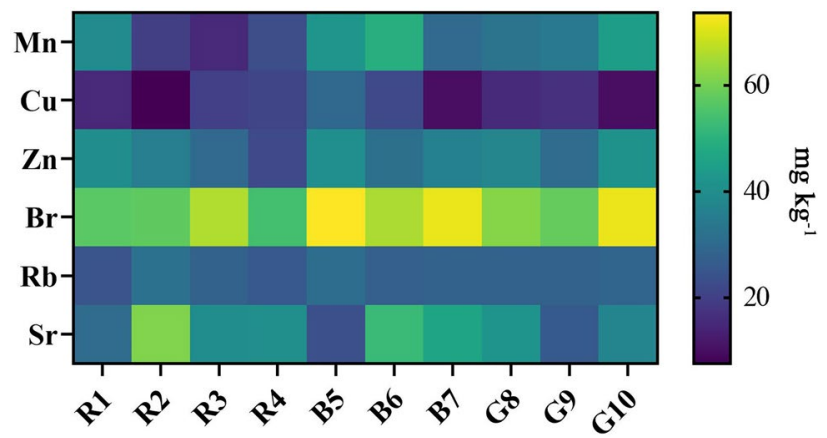

Figure 3. Heat map showing the concentrations (ranging from $\sim 7.8$ to $73.6 \mathrm{mg} \mathrm{kg}^{-1}$ ) of six elements found within the 10 algae species.

\begin{tabular}{|l|c|c|c|c|c|}
\hline \multirow{2}{*}{ Element } & \multicolumn{2}{|l|}{ Mean $\left(\mathbf{m g ~ k g}^{-1}\right) \pm$ SEM per algae group } & \multicolumn{2}{l|}{ ANOVA results } \\
\cline { 2 - 6 } & Rhodophyta & Phaeophyta & Chlorophyta & F (2, 27) & P value \\
\hline $\mathrm{K}$ & $40,836 \pm 2172$ & $42,971 \pm 1412$ & $40,027 \pm 1061$ & 0.6717 & 0.5192 \\
\hline $\mathrm{Cr}$ & $1.62 \pm 0.40$ & $1.01 \pm 0.23$ & $0.646 \pm 0.030$ & 2.769 & 0.0805 \\
\hline $\mathrm{Mn}$ & $24.2 \pm 3.3$ & $40.4 \pm 2.9$ & $37.0 \pm 1.9$ & 9.179 & 0.0009 \\
\hline $\mathrm{Fe}$ & $2475 \pm 160$ & $1634 \pm 63$ & $1638 \pm 55$ & 17.63 & $<0.0001$ \\
\hline $\mathrm{Co}$ & $0.266 \pm 0.022$ & $0.251 \pm 0.031$ & $0.254 \pm 0.030$ & 0.08797 & 0.9160 \\
\hline $\mathrm{Cu}$ & $15.8 \pm 1.6$ & $20.6 \pm 2.9$ & $13.8 \pm 1.1$ & 2.919 & 0.0711 \\
\hline $\mathrm{Zn}$ & $32.2 \pm 2.0$ & $36.5 \pm 1.3$ & $37.3 \pm 1.5$ & 2.672 & 0.0873 \\
\hline $\mathrm{As}$ & $1.16 \pm 0.18$ & $8.06 \pm 1.60$ & $1.61 \pm 0.21$ & 19.97 & $<0.0001$ \\
\hline $\mathrm{Br}$ & $58.6 \pm 1.4$ & $70.3 \pm 1.2$ & $63.9 \pm 2.1$ & 14.50 & $<0.0001$ \\
\hline $\mathrm{Rb}$ & $27.7 \pm 0.9$ & $28.8 \pm 0.6$ & $28.2 \pm 0.1$ & 0.5986 & 0.05567 \\
\hline $\mathrm{Sr}$ & $43.0 \pm 3.4$ & $40.5 \pm 4.4$ & $34.9 \pm 2.4$ & 1.382 & 0.2684 \\
\hline $\mathrm{Zr}$ & $116.2 \pm 13.9$ & $45.6 \pm 1.0$ & $61.3 \pm 9.6$ & 12.43 & 0.0001 \\
\hline $\mathrm{Pb}$ & $1.61 \pm 0.51$ & $5.09 \pm 1.49$ & $1.50 \pm 0.32$ & 5.276 & 0.0116 \\
\hline
\end{tabular}

Table 7. Overall mean elemental concentration per group of algae and ANOVA results.

studies have pointed to Phaeophyta being the most efficient algae in accumulating metals ${ }^{68}$, while others have pointed to Rhodophyta ${ }^{24,50,69}$. These results suggest that the influence of algae type in metal bioaccumulation may be limited, while some specific characteristics such as surface area and growth rates may be more important ${ }^{70}$. As apparent in Table 6, the specific macroalgae tissue evaluated in recent studies has not generally been specified ${ }^{55,56}$. Of note is that heavy metal and trace element concentrations have been observed to vary significantly in macrophytes from salt marshes, specifically between roots, shoots, and leaves ${ }^{36}$. Sáez et al. studied the bioaccumulation of metals in the thallus (blade, stipe, and holdfast) of the kelp Lessonia trabeculata ${ }^{71}$, finding metal-specific affinity in certain parts. A further variable not taken into account has been the life stage of the selected organisms. Future investigations should focus on determining the influence of the particular tissue and of seaweed age on the concentration of heavy metals.

Algae-based heavy metal monitoring may require the use of different species that have better bioaccumulation affinity for different metals. For instance, the highest As concentrations in 12 macroalgae species from China were found in three species from the genus Sargassum ${ }^{24}$. Accordingly, in the present study, S. oligocystum was the species that exhibited the second highest As concentration $\left(10.6 \mathrm{mg} \mathrm{kg}^{-1}\right)$, slightly below P. tetrastromatica $\left(11.9 \mathrm{mg} \mathrm{kg}^{-1}\right.$ ), and significantly greater than the third-highest (C. racemose; $2.27 \mathrm{mg} \mathrm{kg}^{-1}$ ). Similarly, in the present study the highest $\mathrm{Cr}$ concentrations were found in species from the genus Gelidium, also as reported by Pan et al. ${ }^{72}$. The consistency of our results with previous studies supports the necessity of determining genius-specific macroalgae for heavy metal monitoring. Based on our results, we suggest the genus Gelidium for Cr, Padina for $\mathrm{Cu}$ and $\mathrm{As}$, and Sargassum for $\mathrm{Mn}, \mathrm{As}$, and $\mathrm{Pb}$ in monitoring. Future studies may determine the uptake routes for different heavy metals in macroalgae based on their botanical characteristics.

The results of the carcinogenic and non-carcinogenic health risk assessment are displayed in Table 8, while MPI values of the 10 seaweed species are summarized in Fig. 4. The six metals, $\mathrm{Cr}, \mathrm{Pb}, \mathrm{Cu}, \mathrm{Zn}, \mathrm{Co}$, and $\mathrm{As}$, were selected for their potentially hazardous nature at relatively high concentrations and oral $\mathrm{R}_{\mathrm{f}} \mathrm{D}$ data availability. The overall Hazard index was 0.993 , which means the evaluated metals together may not pose a serious health risk to human health. However, $\mathrm{Cd}$ and $\mathrm{Hg}$ were not evaluated in the present study. These heavy metals could potentially contribute to a targeted hazard quotient sufficient to reach a $\mathrm{HI}>1$, thus representing a moderate to high risk for adverse human health effects. In the case of the carcinogenic risk, the $\mathrm{CR}_{\mathrm{t}}$ was calculated as 0.436 . 


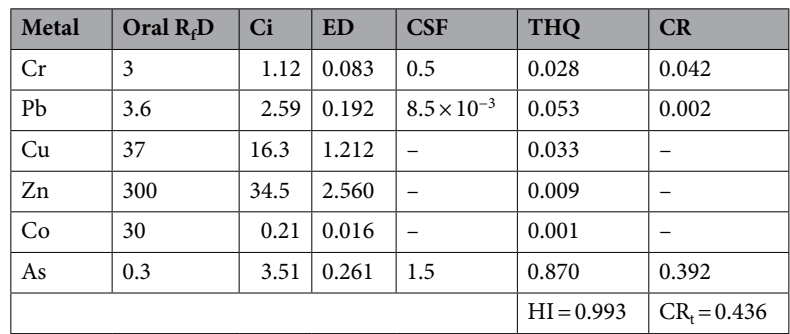

Table 8. Carcinogenic and non-carcinogenic health risk assessment from seaweed consumption in adults in Bangladesh. Oral $\mathrm{R}_{\mathrm{f}} \mathrm{D}$ and CSF values were obtained from Kamuda et al. ${ }^{80}$, and Kortei et al. ${ }^{42}$, and Shams et al. ${ }^{43}$ respectively.

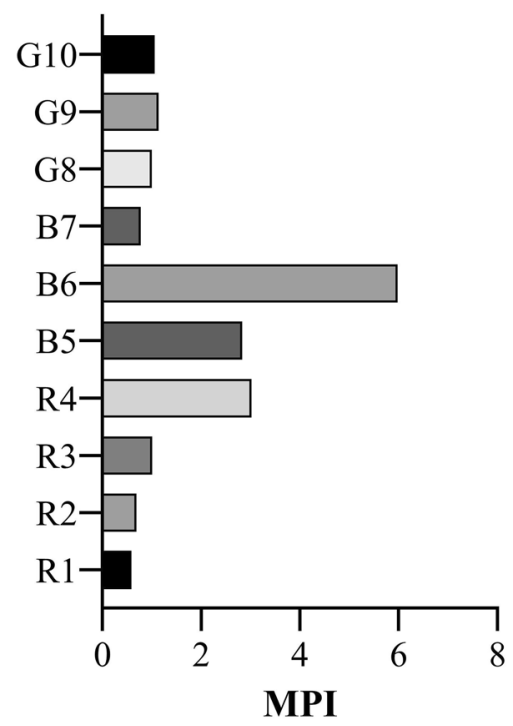

Figure 4. Metal pollution index (MPI) for the ten seaweed species investigated.

Chen et al. ${ }^{72}$ estimated the $\mathrm{HI}$ from dry seaweed consumption in southeastern China by considering the elements $\mathrm{Al}, \mathrm{Cd}, \mathrm{Cr}, \mathrm{Cu}, \mathrm{Hg}, \mathrm{Ni}$, and $\mathrm{Pb}$. The overall mean $\mathrm{HI}$ was calculated as 0.22 , well below our estimations. However, the $\mathrm{HI}$ calculated for the Malaysian population considerably exceeds the health hazard limit $(\mathrm{HI}=4.38)$, although that study presented a lower $\mathrm{CR}_{\mathrm{t}}$ than the present study $(0.29)^{5}$. Although many studies concerning specific populations suggest heavy metal consumption from seaweed may not pose a sizeable health hazard ${ }^{67,73}$, in the present regard of Cox's Bazar the health authorities should look to monitoring heavy metal in consumable seaweeds, taking $\mathrm{HI}$ and $\mathrm{CR}_{\mathrm{t}}$ as indicators of their potential toxicity in areas of high seaweed consumption. In considering the calculated MPI of high toxicity heavy metals $(\mathrm{Cr}, \mathrm{Pb}$, and $\mathrm{As})$ among the various seaweed species, it is suggested that B6 (S. oligocystum) and R4 (G. pusillum) may be the species that present the highest risk of heavy metal ingestion in Cox's Bazar.

The toxicological implications of exposure to heavy metals are widely understood ${ }^{74}$. As an instance, lead poisoning generally links with anemia, affecting three enzymes associated with heme synthesis. In extremely high exposure scenarios, the neurological system can be critically affected ${ }^{75}$. Hexavalent chromium $[\mathrm{Cr}(\mathrm{VI})]$ and As are two well-established heavy metals giving rise to carcinogenic effects ${ }^{76,77}$. Despite the critical health effects associated with the exposure to some of the evaluated heavy metals, seaweed consumption by members of the public remains relatively low, likely insufficient to manifest in severe health effects. Of clinical cases concerning heavy metal tainted foodstuffs, these have mostly been attributed to the consumption of contaminated drinking water ${ }^{78}$.

\section{Conclusions}

Marine macroalgae are regarded as potential biomonitors of heavy metal and trace element pollution. In the present study, the concentrations of 13 elements were determined in 10 species of macroalgae from the coastal area of Cox's Bazar and Saint Martin's Island. The elemental bioaccumulation affinity per species and family type was investigated. Results indicate that some species may serve as better biomonitors than others for certain elements. Based on the agreement with the available literature, we suggest the genus Sargassum for Mn, As, and $\mathrm{Pb}$ monitoring, Gelidium for $\mathrm{Cr}$, and Padina for $\mathrm{Cu}$, and As. Additionally, since many of the species investigated in the present study are cultivated for human consumption, the relevant hazard indices were determined. The index value remains marginally below the limits recommended. However, since other important toxic heavy 
metals, such as Cd, were not evaluated in the present study, the index may be underestimated. Future research must focus on determining the botanic implications and biochemical routes that determine the heavy metal bioaccumulation affinity of key species.

Received: 22 June 2021; Accepted: 29 September 2021

Published online: 25 October 2021

\section{References}

1. Mclntyre, A. \& He, X. Global marine pollution-A brief history. in Encyclopedia of Ocean Sciences 231-235 (Elsevier, 2019). https:// doi.org/10.1016/B978-0-12-409548-9.11429-0.

2. Bonanno, G., Veneziano, V., Raccuia, S. A. \& Orlando-Bonaca, M. Seagrass Cymodocea nodosa and seaweed Ulva lactuca as tools for trace element biomonitoring. A comparative study. Mar. Pollut. Bull. 161, 111743 (2020).

3. Taati, A., Salehi, M. H., Mohammadi, J., Mohajer, R. \& Díez, S. Pollution assessment and spatial distribution of trace elements in soils of Arak industrial area, Iran: Implications for human health. Environ. Res. 187, 109577 (2020).

4. Avigliano, E., Schenone, N. F., Volpedo, A. V., Goessler, W. \& Fernández Cirelli, A. Heavy metals and trace elements in muscle of silverside (Odontesthes bonariensis) and water from different environments (Argentina): Aquatic pollution and consumption effect approach. Sci. Total Environ. 506-507, 102-108 (2015).

5. Khandaker, M. U. et al. Elevated concentrations of metal(Loids) in seaweed and the concomitant exposure to humans. Foods 10, 381 (2021).

6. Ahmed, A. T. \& Osman, A. I. Heavy metals transport from wastewater spills into a coastal aquifer and seawater. Environ. Eng. Manag. J. 18, 2543-2553 (2019).

7. Osuna, F. J., Pavón, E. \& Alba, M. D. Pb2+, Cd2+ and $\mathrm{Hg} 2+$ removal by designed functionalized swelling high-charged micas. Sci. Total Environ. 764, 142811 (2021).

8. Osman, A. I. et al. Production and characterisation of activated carbon and carbon nanotubes from potato peel waste and their application in heavy metal removal. Environ. Sci. Pollut. Res. 26, 37228-37241 (2019).

9. Sari, R. M., Torres, F. G., Troncoso, O. P., De-la-Torre, G. E. \& Gea, S. Analysis and availability of lignocellulosic wastes: Assessments for Indonesia and Peru. Environ. Qual. Manag. https://doi.org/10.1002/tqem.21737 (2021).

10. Chen, H., Osman, A. I., Mangwandi, C. \& Rooney, D. Upcycling food waste digestate for energy and heavy metal remediation applications. Resour. Conserv. Recycl. X 3, 100015 (2019).

11. Farias, D. R., Hurd, C. L., Eriksen, R. S. \& Macleod, C. K. Macrophytes as bioindicators of heavy metal pollution in estuarine and coastal environments. Mar. Pollut. Bull. 128, 175-184 (2018).

12. Maehre, H. K., Malde, M. K., Eilertsen, K.-E. \& Elvevoll, E. O. Characterization of protein, lipid and mineral contents in common Norwegian seaweeds and evaluation of their potential as food and feed. J. Sci. Food Agric. 94, 3281-3290 (2014).

13. Han, Q. \& Liu, D. Macroalgae blooms and their effects on seagrass ecosystems. J. Ocean Univ. China 13, 791-798 (2014).

14. Pawlik-Skowrońska, B., Pirszel, J. \& Brown, M. T. Concentrations of phytochelatins and glutathione found in natural assemblages of seaweeds depend on species and metal concentrations of the habitat. Aquat. Toxicol. 83, 190-199 (2007).

15. Ryan, S., McLoughlin, P. \& O’Donovan, O. A comprehensive study of metal distribution in three main classes of seaweed. Environ. Pollut. 167, 171-177 (2012).

16. Sekar, M. et al. A review on the pyrolysis of algal biomass for biochar and bio-oil: Bottlenecks and scope. Fuel 283, 119190 (2021).

17. Peter, A. P. et al. Microalgae for biofuels, wastewater treatment and environmental monitoring. Environ. Chem. Lett. 19, 2891-2904 (2021).

18. Osman, A. I. et al. Conversion of biomass to biofuels and life cycle assessment: A review. Environ. Chem. Lett. 2021(1), 1-44 (2021).

19. Li, F., Srivatsa, S. C. \& Bhattacharya, S. A review on catalytic pyrolysis of microalgae to high-quality bio-oil with low oxygeneous and nitrogenous compounds. Renew. Sustain. Energy Rev. 108, 481-497 (2019).

20. Torres, F. G. \& De-la-Torre, G. E. Face mask waste generation and management during the COVID-19 pandemic: An overview and the Peruvian case. Sci. Total Environ. 786, 147628 (2021).

21. McHugh, D. J. Prospects for Seaweed Production in Developing Countries. FAO http://www.fao.org/3/y3550e/Y3550E00.htm (2011).

22. Stevenson, M. A., Williamson, N. B., Hardon, D. W. \& Hardon, D. W. The effects of calcium supplementation of dairy cattle after calving on milk, milk fat and protein production, and fertility. N. Z. Vet. J. 47, 53-60 (1999).

23. Chijioke, N. O., Uddin Khandaker, M., Tikpangi, K. M. \& Bradley, D. A. Metal uptake in chicken giblets and human health implications. J. Food Compos. Anal. 85, 103332 (2020).

24. Pan, Y. et al. Screening of seaweeds in the East China Sea as potential bio-monitors of heavy metals. Environ. Sci. Pollut. Res. 25, 16640-16651 (2018).

25. Dadolahi-Sohrab, A., Nikvarz, A., Nabavi, S. M. B., Safahyeh, A. \& Ketal-Mohseni, M. Environmental Monitoring of Heavy Metals in Seaweed and Associated Sediment from the Strait of Hormuz, I.R. Iran. World J. Fish Mar. Sci. 3, 576-589 (2011).

26. Malea, P., Haritonidis, S. \& Kevrekidis, T. Metal content of some green and brown seaweeds from Antikyra Gulf (Greece). Hydrobiologia 310, 19-31 (1995).

27. Besada, V., Andrade, J. M., Schultze, F. \& González, J. J. Heavy metals in edible seaweeds commercialised for human consumption. J. Mar. Syst. 75, 305-313 (2009).

28. Arulkumar, A., Nigariga, P., Paramasivam, S. \& Rajaram, R. Metals accumulation in edible marine algae collected from Thondi coast of Palk Bay, Southeastern India. Chemosphere 221, 856-862 (2019).

29. Rajeshkumar, S. \& Li, X. Bioaccumulation of heavy metals in fish species from the Meiliang Bay, Taihu Lake, China. Toxicol. Rep. 5, 288-295 (2018).

30. DoF. National Fish Week compendium (In Bengali). (2014).

31. Siddiqui, A. A. M., Kashem, M. A., Mondal, M. A. I. \& Shafiuddin, M. Commercially important seaweed cultivation and its potentials for the coastal areas of Cox's Bazar, Bangladesh. Int. J. Fish. Aquat. Stud. 7, 463-470 (2019).

32. Khan, G. Status of production and utilization of seaweeds in Bangladesh. http://www.fao.org/3/ab727e/AB727E03.htm (1990).

33. Hoq, M. E., Haque, M. A. \& Islam, M. M. Feasibility of seaweed culture in Inani and Bakkhali coast of Cox's Bazar, Bangladesh. Pakistan J. Mar. Sci. 25, 27-36 (2016).

34. Rakib, M. R. J., De-la-Torre, G. E., Pizarro-Ortega, C. I., Dioses-Salinas, D. C. \& Al-Nahian, S. Personal protective equipment (PPE) pollution driven by the COVID-19 pandemic in Cox's Bazar, the longest natural beach in the world. Mar. Pollut. Bull. 169, 112497 (2021).

35. Jolly, Y. N., Islam, A. \& Akbar, S. Transfer of metals from soil to vegetables and possible health risk assessment. Springerplus 2, 1-8 (2013).

36. Hossain, M. B., Rakib, R. J., Jolly, Y. N. \& Rahman, M. Metals uptake and translocation in salt marsh macrophytes, Porteresia sp. from Bangladesh coastal area. Sci. Total Environ. 764, 144637 (2021).

37. Rakib, M. R. J. et al. Levels and health risk assessment of heavy metals in dried fish consumed in Bangladesh. Sci. Rep. 11, 14642 (2021). 
38. Ali, M., Biswas, S. K., Akhter, S. \& Khan, A. H. Multielement analysis of water residue: A PIXE measurement. Fresenius' Zeitschrift für Anal. Chemie 322, 755-760 (1985).

39. Giusti, L. Heavy metal contamination of brown seaweed and sediments from the UK coastline between the Wear river and the Tees river. Environ. Int. 26, 275-286 (2001).

40. USEPA. Concepts, Methods, and Data Sources For Cumulative Health Risk Assessment of Multiple Chemicals, Exposures and Effects: A Resource Document. https://cfpub.epa.gov/ncea/risk/recordisplay.cfm?deid=190187 (2008).

41. USEPA. 2012 Edition of the Drinking Water Standards and Health Advisories. (2012).

42. Kortei, N. K. et al. Health risk assessment and levels of toxic metals in fishes (Oreochromis noliticus and Clarias anguillaris) from Ankobrah and Pra basins: Impact of illegal mining activities on food safety. Toxicol. Rep. 7, 360-369 (2020).

43. Shams, M. et al. Heavy metals exposure, carcinogenic and non-carcinogenic human health risks assessment of groundwater around mines in Joghatai, Iran. Int. J. Environ. Anal. Chem. https://doi.org/10.1080/03067319.2020.1743835 (2020).

44. El-Said, G. F. \& El-Sikaily, A. Chemical composition of some seaweed from Mediterranean Sea coast. Egypt. Environ. Monit. Assess. 185, 6089-6099 (2012).

45. Parjikolaei, B. R. et al. Valuable biomolecules from Nine North Atlantic Red Macroalgae: Amino acids, fatty acids, carotenoids, minerals and metals. Nat. Resour. 7, 157-183 (2016).

46. Bikker, P. et al. Biorefinery of the green seaweed Ulva lactuca to produce animal feed, chemicals and biofuels. J. Appl. Phycol. 28, 3511-3525 (2016).

47. Villares, R., Fernández-Lema, E. \& López-Mosquera, E. Seasonal variations in concentrations of macro- and micronutrients in three species of brown seaweed. Bot. Mar. 56, 49-61 (2013).

48. Hue, N. V. \& Silva, J. A. Organic Soil Amendments for Sustainable Agriculture: Organic Sources of Nitrogen, Phosphorus, and Potassium. in Plant Nutrient Management in Hawaii's Soils, Approaches for Tropical and Subtropical Agriculture (eds. Silva, J. A. \& Uchida, R.) 133-144 (College of Tropical Agriculture and Human Resources, University of Hawaii, 2000).

49. Khandaker, M. U., Heffny, N., Adillah, B., Amin, Y. M. \& Bradley, D. A. Elevated concentration of radioactive potassium in edible algae cultivated in Malaysian seas and estimation of ingestion dose to humans. Algal Res. 38, 101386 (2019).

50. Filippini, M. et al. Heavy metals and potential risks in edible seaweed on the market in Italy. Chemosphere 263, 127983 (2021).

51. Lunde, G. Analysis of trace elements in seaweed. J. Sci. Food Agric. 21, 416-418 (1970).

52. Osman, A. I., Ahmed, A. T., Johnston, C. R. \& Rooney, D. W. Physicochemical characterization of miscanthus and its application in heavy metals removal from wastewaters. Environ. Prog. Sustain. Energy 37, 1058-1067 (2018).

53. ANSES. ANSES OPINION on 'maximum cadmium levels for seaweed intended for human consumption'. https://www.anses.fr/en/ system/files/ERCA2017SA0070EN.pdf (2017).

54. FAO. Codex general standard for contaminants and toxins in food and feed. http://www.fao.org/fao-who-codexalimentarius/shproxy/en/?lnk=1\&url=https\%253A\%252F\%252Fworkspace.fao.org\%252Fsites\%252Fcodex\%252FMeetings\%252FCX-735-12\% 252FWD\%252Fcf12_INF01x.pdf (1995).

55. Ghosn, M. et al. Assessment of trace element contamination and bioaccumulation in algae (Ulva lactuca), bivalves (Spondylus spinosus) and shrimps (Marsupenaeus japonicus) from the Lebanese coast. Reg. Stud. Mar. Sci. 39, 101478 (2020).

56. Malea, P., Chatziapostolou, A. \& Kevrekidis, T. Trace element seasonality in marine macroalgae of different functional-form groups. Mar. Environ. Res. 103, 18-26 (2015).

57. Martín-León, V. et al. Human exposure to toxic metals (Cd, $\mathrm{Pb}, \mathrm{Hg})$ and nitrates (NO3-) from seaweed consumption. Appl. Sci. 11, 6934 (2021).

58. Chakraborty, S., Bhattacharya, T., Singh, G. \& Maity, J. P. Benthic macroalgae as biological indicators of heavy metal pollution in the marine environments: A biomonitoring approach for pollution assessment. Ecotoxicol. Environ. Saf. 100, 61-68 (2014).

59. Torres, F. G. \& De-la-Torre, G. E. Environmental pollution with antifouling paint particles: Distribution, ecotoxicology, and sustainable alternatives. Mar. Pollut. Bull. 169, 112529 (2021).

60. Huerta-Diaz, M. A., de León-Chavira, F., Lares, M. L., Chee-Barragán, A. \& Siqueiros-Valencia, A. Iron, manganese and trace metal concentrations in seaweeds from the central west coast of the Gulf of California. Appl. Geochemistry 22, 1380-1392 (2007).

61. Roleda, M. Y. et al. Chemical profiling of the Arctic sea lettuce Ulva lactuca (Chlorophyta) mass-cultivated on land under controlled conditions for food applications. Food Chem. 341, 127999 (2021).

62. Cherry, P., O’hara, C., Magee, P. J., Mcsorley, E. M. \& Allsopp, P. J. Risks and benefits of consuming edible seaweeds. Nutr. Rev. 77, 307-329 (2019).

63. García-Casal, M. N., Ramírez, J., Leets, I., Pereira, A. C. \& Quiroga, M. F. Antioxidant capacity, polyphenol content and iron bioavailability from algae (Ulva sp., Sargassum sp. and Porphyra sp.) in human subjects. Br. J. Nutr. 101, 79-85 (2009).

64. Malea, P. \& Kevrekidis, T. Trace element patterns in marine macroalgae. Sci. Total Environ. 494-495, 144-157 (2014).

65. Salomone, V. N., Riera, M., Cerchietti, L., Custo, G. \& Muniain, C. Seasonal determination of trace and ultra-trace content in Macrocystis pyrifera from San Jorge Gulf (Patagonia) by Total Reflection X-ray Fluorescence. Spectrochim. Acta Part B At. Spectrosc. 131, 74-78 (2017).

66. Cabrita, M. T., Vale, C. \& Rauter, A. P. Halogenated compounds from Marine Algae. Mar. Drugs 8, 2301-2317 (2010).

67. Rubio, C. et al. Metals in edible seaweed. Chemosphere 173, 572-579 (2017).

68. Laib, E. \& Leghouchi, E. Cd, Cr, Cu, Pb, and $\mathrm{Zn}$ concentrations in Ulva lactuca, Codium fragile, Jania rubens, and Dictyota dichotoma from Rabta Bay, Jijel (Algeria). Environ. Monit. Assess. 184, 1711-1718 (2012).

69. Lin, Z., Li, J., Luan, Y. \& Dai, W. Application of algae for heavy metal adsorption: A 20-year meta-analysis. Ecotoxicol. Environ. Saf. 190, $110089(2020)$.

70. Akcali, I. \& Kucuksezgin, F. A biomonitoring study: Heavy metals in macroalgae from eastern Aegean coastal areas. Mar. Pollut. Bull. 62, 637-645 (2011).

71. Sáez, C. A. et al. Variation in patterns of metal accumulation in thallus parts of Lessonia trabeculata (Laminariales; Phaeophyceae): Implications for biomonitoring. PLoS ONE 7, e50170 (2012).

72. Chen, Q., Pan, X. D., Huang, B. F. \& Han, J. L. Distribution of metals and metalloids in dried seaweeds and health risk to population in southeastern China. Sci. Rep. 8, 1-7 (2018).

73. Desideri, D. et al. Essential and toxic elements in seaweeds for human consumption. J. Toxicol. Environ. Heal. Part A Curr. Issues 79, 112-122 (2016).

74. Ali, H., Khan, E. \& Ilahi, I. Environmental chemistry and ecotoxicology of hazardous heavy metals: Environmental persistence, toxicity, and bioaccumulation. J. Chem. 2019, 6730305 (2019).

75. Abdulla, M. Lead. Essent. Toxic Trace Elem. Vitam. Hum. Heal. https://doi.org/10.1016/B978-0-12-805378-2.00014-0 (2020).

76. Lou, J. et al. Environmentally induced ribosomal DNA (rDNA) instability in human cells and populations exposed to hexavalent chromium [Cr (VI)]. Environ. Int. 153, 106525 (2021).

77. Choong, T. S. Y., Chuah, T. G., Robiah, Y., Gregory Koay, F. L. \& Azni, I. Arsenic toxicity, health hazards and removal techniques from water: an overview. Desalination 217, 139-166 (2007).

78. Tumolo, M. et al. Chromium pollution in European water, sources, health risk, and remediation strategies: An overview. Int. J. Environ. Res. Public Heal. 17, 5438 (2020).

79. Chen, Y. et al. An investigation of toxic metal levels $(\mathrm{Pb}, \mathrm{Cd}, \mathrm{Cr}, \mathrm{As}, \mathrm{Hg})$ in dried porphyra and laminaria collected from coastal cities, China. Biol. Trace Elem. Res. 2021, 1-11. https://doi.org/10.1007/S12011-020-02509-W (2021). 
80. Kamunda, C., Mathuthu, M. \& Madhuku, M. Health Risk Assessment of heavy metals in soils from Witwatersrand Gold Mining Basin, South Africa. Int. J. Environ. Res. Public Health 13, 663 (2016).

\section{Acknowledgements}

The authors acknowledge the assistance provided by the Atmospheric and Environmental Chemistry Laboratory for providing all necessary research facilities, also Taif University Researchers Supporting Project number (TURSP-2020/163), Taif 21944, Saudi Arabia.

\section{Author contributions}

M.R.J.R.: Conceptualization, Methodology, Validation, Sample analysis, Data curation, Supervision, Investigation, Project administration, Writing-Original Draft, Writing-Review and Editing. G.E.D.-l.-T.; D.C.D.-S.; C.I.P.-O.; Y.N.J.; M.U.K.: Investigation, Data Curation, Writing, Review and Editing. A.A.; A.S.A.A.; D.A.B.: Review and Editing.

\section{Competing interests}

The authors declare no competing interests.

\section{Additional information}

Supplementary Information The online version contains supplementary material available at https://doi.org/ 10.1038/s41598-021-99750-7.

Correspondence and requests for materials should be addressed to M.J.R.

Reprints and permissions information is available at www.nature.com/reprints.

Publisher's note Springer Nature remains neutral with regard to jurisdictional claims in published maps and institutional affiliations.

Open Access This article is licensed under a Creative Commons Attribution 4.0 International format, as long as you give appropriate credit to the original author(s) and the source, provide a link to the Creative Commons licence, and indicate if changes were made. The images or other third party material in this article are included in the article's Creative Commons licence, unless indicated otherwise in a credit line to the material. If material is not included in the article's Creative Commons licence and your intended use is not permitted by statutory regulation or exceeds the permitted use, you will need to obtain permission directly from the copyright holder. To view a copy of this licence, visit http://creativecommons.org/licenses/by/4.0/.

(C) The Author(s) 2021 